\title{
Vanadium bioavailability in soils amended with blast furnace slag
}

Maja A. Larsson ${ }^{\mathrm{a}, *}$, Stijn Baken ${ }^{\mathrm{b}}$, Erik Smolders ${ }^{\mathrm{b}}$, Francesco Cubadda $^{\mathrm{c}}$ and Jon Petter Gustafsson ${ }^{\mathrm{a}, \mathrm{d}}$

${ }^{a}$ Department of Soil and Environment, Swedish University of Agricultural Sciences, Box 7014, 75007 Uppsala, Sweden

${ }^{\mathrm{b}}$ Department of Earth and Environmental Sciences, Leuven University, Kasteelpark Arenberg 20 bus 2459,3001 Leuven, Belgium

${ }^{c}$ Department of Food Safety and Veterinary Public Health, Istituto Superiore di Sanità, Viale Regina Elena 299, Rome, 00161, Italy

${ }^{\mathrm{d}}$ Division of Land and Water Resources Engineering, KTH Royal Institute of Technology, Brinellvägen 28, 100 44 Stockholm, Sweden

Maja A. Larsson (Corresponding author): maja.larsson@slu.se

Phone: +46-18-671243

Fax: $+46-18-673156$

Stijn Baken: stijn.baken@ees.kuleuven.be

Erik Smolders: erik.smolders@ees.kuleuven.be

Francesco Cubadda: francesco.cubadda@iss.it

Jon Petter Gustafsson: jon-petter.gustafsson@slu.se 


\begin{abstract}
Blast furnace (BF) slags are commonly applied as soil amendments and in road fill material. In Sweden they are also naturally high in vanadium. The aim of this study was to assess the vanadium bioavailability in BF slags when applied to soil. Two soils were amended with up to $29 \% \mathrm{BF}$ slag (containing $800 \mathrm{mg} \mathrm{V} \mathrm{kg}^{-1}$ ) and equilibrated outdoors for 10 months before conducting a barley shoot growth assay. Additional soil samples were spiked with dissolved vanadate(V) for which assays were conducted two weeks (freshly spiked) and 10 months (aged) after spiking. The BF slag vanadium was dominated by vanadium(III) as shown by V K-edge XANES spectroscopy. In contrast, results obtained by HPLC-ICP-MS showed that vanadium(V), the most toxic vanadium species, was predominant in the soil solution. Barley shoot growth was not affected by the BF slag additions. This was likely due to limited dissolution of vanadium from the BF slag, preventing an increase of dissolved vanadium above toxic thresholds. The difference in vanadium bioavailability among treatments was explained by the vanadium concentration in the soil solution. It was concluded that the vanadium in BF slag is sparingly available. These findings should be of importance in environmental risk assessment.
\end{abstract}

Keywords: vanadium; speciation; blast furnace slag; soil; phytotoxicity; bioavailability 


\section{Introduction}

More than 1500 million tons of steel is produced every year worldwide [1]. This leads to the generation of at least twice as much waste materials. A large fraction of the waste materials consists of blast furnace (BF) slag, which is formed during the making of pig iron by residues from the ore, reducing agents (e.g. coke) and fluxes (e.g. limestone). Due to its alkalinity and physical properties, BF slags are used as soil amendments or applied in road materials and cement [2]. A potential risk with the use of BF slag is leaching of trace elements [3]. The trace element concentrations of the BF slags depend mainly on the background concentrations in the ore. The iron ore mined in Sweden is found in an area with naturally high vanadium concentrations [4]. This results in BF slags that are naturally high in vanadium and concentrations can reach above $500 \mathrm{mg} \mathrm{V} \mathrm{kg}^{-1}$ [5]. The BF slag is considered relatively inert [6] and data of vanadium leaching from BF slags are scarce [7]. Availability tests, which estimate the potential leaching, have shown that about $10 \%$ of the vanadium in BF slag can be leached [8]. Generally, the $\mathrm{pH}$ and redox conditions are the main factors affecting the solubility of trace elements in slags. Oxidized conditions under natural ageing enhance vanadium solubility $[8,9]$.

Vanadium is often strongly retained in soils [10-13], and metal (hydr)oxides are important for vanadium sorption $[14,15]$. The retention of vanadium in soils is most pronounced around $\mathrm{pH} 4$ [11]. Vanadium may be leached either at very low $\mathrm{pH}(<4)$, or at high $\mathrm{pH}(>8)$, due to $\mathrm{pH}$-dependent differences in sorption affinity $[10,16]$. The $\mathrm{pH}$ value also affects vanadium speciation. Vanadium is a redox-sensitive element that can exist in several different oxidation states, of which +4 and +5 are the most soluble ones in the environment [17]. Vanadium(IV) is an oxocation stable at low $\mathrm{pH}$ and is readily complexed to humic substances [18]. Pentavalent vanadate may be stable above pH 3.6 and sorbs as an oxyanion to iron (hydr)oxides, e.g. goethite [19]. Vanadate(V) is the most commonly occurring redox species in soils and also the most toxic [20,21]. Due to its similarity to phosphate, vanadate can inhibit enzymes such as ATPase and alkaline phosphatases.

The median vanadium concentration in European top soils, based on aqua regia digestion, is $33 \mathrm{mg} \mathrm{V} \mathrm{kg}^{-1} \mathrm{soil}_{\text {, }}$ and the range is from a few $\mathrm{mg} \mathrm{kg}^{-1}$ up to almost $300 \mathrm{mg} \mathrm{V} \mathrm{kg}^{-1}$ [22]. The guideline value for sensitive land use is set to $100 \mathrm{mg} \mathrm{V} \mathrm{kg}^{-1}$ by the Swedish EPA [23]. Vanadium phytotoxicity in soil varies across soils and plant species. For example, the toxicity (EC50) of vanadate(V) to barley and tomato seedlings was tested in five

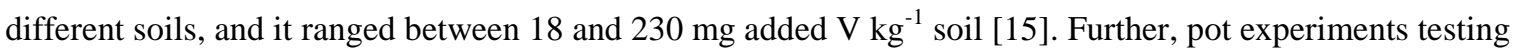
phytotoxicity by adding $\mathrm{V}_{2} \mathrm{O}_{5}$ to an artificial soil at different nutrient levels had similar ranges of EC50 values 
(21-180 $\left.\mathrm{mg} \mathrm{V} \mathrm{kg}^{-1}\right)$ in a selection of five different plant species [24]. The wide range of threshold values becomes smaller if expressed as vanadium concentrations in soil solution [15, 25].

The leaching of vanadium from alkaline waste materials depends on its redox speciation [7]. The vanadium speciation of BF slags is however generally unknown. The use of V K-edge XANES spectroscopy to determine vanadium speciation in basic oxygen furnace (BOF) slags revealed a 50:50 mixture of vanadium(III) and vanadium(V) in the material [26]. During natural ageing, the fraction of the more soluble vanadium(V) species increased [9]. In contrast to the BOF slag, the BF slag is produced under reductive conditions by adding coke as a reducing agent, and it can therefore be hypothesized that vanadium in BF slags occurs in even lower valence states.

The objective of this study was to determine the bioavailability of vanadium in BF slags added to soil. It was hypothesized that only a small fraction of the total vanadium in the slags is accessible as vanadate(V), the most toxic redox species of vanadium. Different concentrations of two commercially used BF slags, M-kalk and Merit 5000, were added to two soils and aged for almost one year. Barley shoot growth was thereafter tested in the soils and the plant uptake of vanadium was compared to that from soils with freshly added vanadate(V). Such a comparison allows us to translate soil vanadium limits, based on toxicity tests with freshly added vanadate(V), into soil limits for BF slags. Bioavailability across different vanadium treatments and soils was evaluated by using the vanadium plant uptake and applying the soil solution perspective. 


\section{Materials and Methods}

\subsection{Blast furnace slags and soils}

Two blast furnace (BF) slags, M-kalk and Merit 5000, were mixed into two different soils, Pustnäs and Säby, in different concentrations (Table 1 and Table 2). The slags were commercially available products, produced in the SSAB Oxelösund steelworks between 2006 and 2009. Total element analysis was performed by fusion with lithium metaborate followed by dissolution in diluted nitric acid. The results showed that the two BF slag contained about $800 \mathrm{mg} \mathrm{V} \mathrm{kg}^{-1}$ (Table 1). The soils were collected in 2009 by sampling down to $20 \mathrm{~cm}$ depth with a spade. Subsequently, the soils were air-dried, sieved to $2 \mathrm{~mm}$, and stored in sealed plastic containers until further use. A detailed description of soil properties is provided in Larsson et al. [15].

\subsection{Vanadium speciation analysis: XANES spectroscopy and HPLC-ICP-MS}

Vanadium valence states in the two BF slags were determined by X-ray absorption near edge structure (XANES) spectroscopy at the vanadium K edge. In addition, XANES spectra were recorded for one reference sample of each soil and for one sample that had been equilibrated with dissolved vanadate(V) at $114.5 \mathrm{mg} \mathrm{kg}^{-1}$ (see Supplementary content). The measurements were performed at the wiggler beam line 4-3, Stanford Synchrotron Radiation Lightsource (SSRL), Stanford, USA. The station operated at $3.0 \mathrm{GeV}$ with a current of 97-100 mA, using a $\mathrm{Si}[111]$ double crystal monochromator. Measurements were performed in fluorescence mode using a 13 element Ge array fluorescence detector. The spectra were collected at the vanadium K-edge of $5465 \mathrm{eV}$ [27]. Three and four scans were collected for M-kalk and Merit 5000, respectively. Five vanadium laboratory standards were measured; $\mathrm{V}_{2} \mathrm{O}_{3}(\mathrm{~s}), \mathrm{V}_{2} \mathrm{O}_{4}(\mathrm{~s}), \mathrm{VO}^{2+}(\mathrm{aq}), \mathrm{V}_{2} \mathrm{O}_{5}(\mathrm{~s})$ and $\mathrm{H}_{2} \mathrm{VO}_{4}{ }^{-}(\mathrm{aq})$. The oxides were products from Sigma-Aldrich (purity of $98 \%\left(\mathrm{~V}_{2} \mathrm{O}_{3}(\mathrm{~s})\right), 99.9 \%\left(\mathrm{~V}_{2} \mathrm{O}_{4}(\mathrm{~s})\right)$ and $\left.>99.6 \%\left(\mathrm{~V}_{2} \mathrm{O}_{5}(\mathrm{~s})\right)\right)$ and were diluted with 75 weight- $\%$ inert boron nitride before measurement. The $\mathrm{VO}^{2+}(\mathrm{aq})$ and $\mathrm{H}_{2} \mathrm{VO}_{4}^{-}(\mathrm{aq})$ solutions were prepared from the dissolution of $\mathrm{VOSO}_{4}(\mathrm{~s})\left(\right.$ Alfa Aesar) and $\mathrm{NaVO}_{3}(\mathrm{~s})$ (Sigma-Aldrich), respectively, in deionized water to stock solutions of $15 \mathrm{mM}$. All samples were measured over an energy range from 5235 to $5645 \mathrm{eV}$ with an experimental resolution of $\pm 0.5 \mathrm{eV}$.

The collected spectra were processed in the Athena software, version 0.8.056 [28], where replicate scans were aligned, merged and energy-calibrated to that of the reference foil. The first derivative maximum of the K-edge of vanadium metal, $\mathrm{E}_{0}$, was set to $5465 \mathrm{eV}$. All samples were normalized by fitting two parallel lines in the preedge and post-edge regions, according to Wong et al. [29]. The pre-edge peak area and intensity of the spectra 
were thereafter determined from the peak-fit function in Athena, by which the base-line was fitted with an best fit was selected based on the lowest R-factor:

$\mathrm{R}=\frac{\Sigma(\text { data }-f i t)^{2}}{\Sigma\left(\text { data }^{2}\right)}$

The R-factor varied from 0.01 to 0.0004 between samples. The $\mathrm{E}_{1 / 2}$ (the energy where the normalized intensity of the main edge equals 0.5 ) was determined from the normalized spectra.

EDTA complexation followed by HPLC-ICP-MS measurement was applied to determine the vanadium oxidation state in water extracts of the slags and in the dissolved phase of the soils. For the slags, $100 \mathrm{~mL}$ of deionized Millipure water was added to $50 \mathrm{~g}$ of each BF slag (1 replicate) and equilibrated in an end-over-end shaker for $24 \mathrm{~h}$. The two soils were subjected to sorption experiments in which $30 \mathrm{~mL}$ solution containing 0.03 $\mathrm{M} \mathrm{NaNO}_{3}$ and $0.15 \mathrm{mM}$ vanadium was added to $2 \mathrm{~g}$ of soil $\left(114.5 \mathrm{mg} \mathrm{V} \mathrm{kg} \mathrm{soil}{ }^{-1}\right)$. Two samples were prepared for each soil, one with additions of $\operatorname{vanadyl}(\mathrm{IV}), \mathrm{VO}^{2+}(\mathrm{aq})$, and one with additions of vanadate( $\left.\mathrm{V}\right), \mathrm{H}_{2} \mathrm{VO}_{4}{ }^{-}(\mathrm{aq})$, which were prepared as described above. The suspensions were equilibrated in an end-over-end shaker for 10 days. After equilibration, all samples (slags and soils) were centrifuged (16800 $g$ for $30 \mathrm{~min}$ at $4{ }^{\circ} \mathrm{C}$ ) and the $\mathrm{pH}$ value in the supernatant was subsequently measured. The remaining solution phase was filtered $(0.45 \mu \mathrm{m}$ followed by $0.22 \mu \mathrm{m}$ ) and $50 \mathrm{mM} \mathrm{Na} \mathrm{A}_{2}$ EDTA was added. EDTA forms very stable complexes with both $\operatorname{vanadium}(\mathrm{IV})[\mathrm{VO}(\mathrm{EDTA})]^{2-}$ and vanadium $(\mathrm{V})\left[\mathrm{VO}_{2}(\mathrm{EDTA})\right]^{3-}$, which prevent the redistribution of vanadium species during analysis [30]. The total concentration and speciation of vanadium in the solutions were measured within one week by DRC-ICP-MS and HPLC-ICP-MS, respectively, according to Aureli et al. [31]. An Elan DRC II ICP-MS (Perkin Elmer-Sciex, Norwalk, CT, USA) instrument and a metal-free HPLC apparatus consisting of Perkin Elmer Series 200 LC pumps equipped with a Series 200 autosampler were used for analytical determination.

\subsection{Soil treatments}

The two soils were amended with four different concentrations of M-kalk and Merit $5000(0.1,1,10$ and $29 \%)$ in four replicates per concentration. These amendments corresponded to vanadium additions of between 0.8 and $230 \mathrm{mg} \mathrm{kg}^{-1}$ soil, based on the total vanadium concentration of $800 \mathrm{mg} \mathrm{kg}^{-1} \mathrm{BF}$ slag. The slags were added to the soil to a total weight of $5 \mathrm{~kg}$. The slag-amended soils were then homogenized with a garden spade and moistened with $500 \mathrm{~mL}$ of deionized water. In addition, four replicates with no slag amendments, and four replicates with 5 
$\% \mathrm{CaCO}_{3}$ additions as a lime control were prepared. In all cases, $100 \mathrm{~mL}$ of water per $\mathrm{kg}$ soil was added. The

soils were placed in plastic pots with free drainage and kept outdoors in Uppsala, Sweden, for 10 months.

Subsequently, the soils were air-dried and stored in sealed plastic containers during three to four months until the plant growth assay was performed.

Shoot growth tests performed on the same soils but treated with a range of vanadate $(\mathrm{V})$ concentrations $(0,3.2$, $10,32,100,320,1000$ and $3200 \mathrm{mg} \mathrm{V} \mathrm{kg}^{-1}$ soil) were also included in this study. One set of the soils was referred to as "freshly spiked" soils. This set of soils, was amended with the dissolved vanadate(V) salt two weeks before the shoot growth test. Another set of the same soils, referred to as "aged" soils, was spiked with the above vanadate $(\mathrm{V})$ concentrations and kept outside for 10 months, in the same manner as described above for the slag amended soils, before conducting the assay. A detailed description of the freshly spiked and aged soils is found in Larsson et al. [15] and Baken et al. [25], respectively.

\subsection{Barley shoot growth assay}

The barley shoot growth assay was performed according to ISO 11269-2 [32]. Before starting the assay, all replicates for each soil treatment were separately wetted and incubated in the dark in $20{ }^{\circ} \mathrm{C}$ for one week and then fertilized with $50 \mathrm{mg} \mathrm{P} \mathrm{kg}^{-1}$ and $100 \mathrm{mg} \mathrm{N} \mathrm{kg}^{-1}$ (as $\mathrm{KH}_{2} \mathrm{PO}_{4}$ and $\mathrm{KNO}_{3}$ respectively). After another week of incubation, approximately $500 \mathrm{~g}$ of each soil sample was placed in a pot, and ten germinated summer barley seeds $(H$. vulgare L.) were evenly sown in each pot. The seeds were placed about $0.5 \mathrm{~cm}$ below the soil surface and then covered with $1 \mathrm{~cm}$ of inert plastic beads to minimize water losses. The pots were placed in a growth chamber with $70 \%$ humidity, with the light (intensity $650 \mathrm{~mol}$ photons $\mathrm{m}^{-2} \mathrm{~s}^{-1}$ ) set to $16 \mathrm{~h}$ per day at a temperature of $20{ }^{\circ} \mathrm{C}$ and the 8 dark hours set to a temperature of $16^{\circ} \mathrm{C}$. As soon as more than $70 \%$ of the shoots in each pot had emerged (after three days) they were reduced to five shoots per pot. Water losses were compensated on a daily basis. After 12 days, the plants were cut just above the soil surface, dried at $70^{\circ} \mathrm{C}$ and weighed. The shoot assays on all BF slag-amended soils and control were performed at the same time in the same growth chamber. The freshly spiked and aged soils were placed in the same chamber at identical conditions and were planted with the same stock of seeds.

\subsection{Soil and plant analysis}

The vanadium concentrations in the amended soils were determined by aqua regia digestion on one replicate per soil treatment. For quality control, reference samples with values of aqua regia-soluble vanadium, the standard reference material NRC Canada LKSD-4 with a vanadium concentration of $32 \mathrm{mg} \mathrm{V} \mathrm{kg}{ }^{-1}$ [33] and the soil 
sample WEPAL 921 with a consensus vanadium concentration of $51.2 \mathrm{mg} \mathrm{kg}^{-1}$ [34] were included. The range of recoveries was $87-104 \%$.

The concentration of dissolved vanadium in the soils was determined for all three vanadium treatments. The soils amended with BF slag were subjected to $\mathrm{CaCl}_{2}$ extractions in which $20 \mathrm{~g}$ of soil was equilibrated with $20 \mathrm{~mL}$ of $0.01 \mathrm{M} \mathrm{CaCl}_{2}$ (two replicates per soil treatment). The suspensions were equilibrated in an end-over end shaker for 24 hours and the supernatant was subsequently isolated by centrifugation (3000 $g$ for 15 min) and membrane filtration $(0.45 \mu \mathrm{m})$. For the freshly spiked and aged soils, the dissolved vanadium concentrations were determined by extraction of the pore water by centrifuging the soils at $3000 \mathrm{~g}$ [25]. All solutions were analyzed for major elements and vanadium (ICP-OES, Perkin Elmer Optima 3300DV, vanadium measured at 290.880 $\mathrm{nm}$ ), dissolved organic carbon (non-purgeable organic carbon, Analytik Jena Multi N/C 2100) and pH. Extractions with $0.01 \mathrm{M} \mathrm{CaCl}_{2}$ were also performed on some of the freshly spiked soils (dose $32 \mathrm{mg} \mathrm{V} \mathrm{kg}^{-1}$, Pustnäs and $320 \mathrm{mg} \mathrm{V} \mathrm{kg}^{-1}$, Säby) and the aged soils (320 mg V kg${ }^{-1}$, Säby) to compare the vanadium composition between the two types of extracts. The $\mathrm{CaCl}_{2}$ extracts underestimated the vanadium concentration in the pore water by a maximum of factor two, and the two extraction methods were considered compatible.

The vanadium concentration in the dry barley leaf shoots was obtained after digestion of $200 \mathrm{mg}$ of plant material (two replicates per soil treatment) in $1 \mathrm{~mL}$ of nitric acid at $140{ }^{\circ} \mathrm{C}$. The digests were diluted and the major elements and the vanadium concentrations were measured (ICP-OES).

\subsection{Statistical analysis}

The effects of BF slag on barley shoot growth were determined by Dunnett's test $(\mathrm{p}<0.05)$. The growth of barley shoots in the soils amended with BF slag was compared to that in the soil with no BF slag addition.

The plant vanadium concentrations were related to the soil vanadium concentrations by linear regression for each of the four different vanadium treatments and for each soil. Data from the freshly spiked and aged soils were included for samples up to a maximum soil vanadium concentration of $220 \mathrm{mg} \mathrm{V} \mathrm{kg}{ }^{-1}$ to compare the different treatments over the same concentration range. The slopes of the aged and BF slag amended soils (slope) were divided by the slope of the corresponding freshly spiked soil (slope, fresh) to determine the relative vanadium bioavailability $\left(\mathrm{RBA}_{\mathrm{V}}\right)$ of aged and $\mathrm{BF}$ slag-derived vanadium, i.e.

$R B A_{V}=\frac{\text { slope }}{\text { slope,fresh }}$ 
The standard error on $\mathrm{RBA}_{\mathrm{V}}$ is:

$S E_{R B A_{V}}=\mathrm{RBA}_{V} \cdot \sqrt{\left(\frac{S E_{\text {slope }, \text { fresh }}}{\text { slope,fresh }}\right)^{2}+\left(\frac{S E_{\text {slope }}}{\text { slope }}\right)^{2}}$

The relative bioavailability (RBA) term is used by US-EPA and describes the fraction of a contaminant that is absorbed into the body from soil ingestion as compared to the fraction that is absorbed from a reference material, e.g. soluble metal added to a diet. In our case, the reference material is the freshly spiked soil. A similar approach was used by Smolderset al. [35] when they evaluated the leaching-ageing factor quantifying the differences in ED10 values between freshly spiked and aged soils. An RBA factor below unity indicates reduced bioavailability in relation to the freshly spiked soils. 


\section{Results and discussion}

\subsection{Vanadium concentrations and speciation in slags and soils}

Vanadium is generally not considered in the risk assessments of trace elements from ferrous BF slags due to the low concentrations $[3,7]$. However, the BF slags used in this study, M-kalk and Merit 5000, were high in vanadium because of naturally high vanadium levels in the iron ore [4]. The total vanadium concentrations in the M-Kalk and Merit 5000 were 803 and $783 \mathrm{mg} \mathrm{kg}^{-1}$ respectively, of which 85 and $72 \%$ was recovered by aqua regia digestion (Table 1). These concentrations were higher than those normally reported for BF slags, $<500 \mathrm{mg}$ $\mathrm{V} \mathrm{kg}^{-1}[6,8]$. Also, the aqua regia-extracted vanadium concentrations in the slags were between 13 and 24 times higher than the concentration in the two soils, Pustnäs and Säby, which contained 28 and $43 \mathrm{mg} \mathrm{V} \mathrm{kg}^{-1}$ respectively (Table 2). These concentrations are close to the median vanadium concentration in European top soils, being $33 \mathrm{mg} \mathrm{kg}^{-1}$ [22].

Vanadium speciation in the BF slags was evaluated by vanadium K edge XANES spectroscopy. The spectra of the measured standards were in accordance with the literature $[29,36]$ showing an increase in pre-edge peak intensity and $\mathrm{E}_{1 / 2}$ with increasing oxidation state (Table $\mathrm{S} 1$ ). When the pre-edge peak intensity and the $\mathrm{E}_{1 / 2}$ of the XANES spectra of the two BF slags were compared to those of the standards, it was possible to estimate the predominating valence state, which was +3 (Figure 1). The normalized pre-edge peak intensity of both slags was 0.06 , which was somewhat lower than the one of the $\mathrm{V}_{2} \mathrm{O}_{3}$ standard (0.12). Further, the $\mathrm{E}_{1 / 2}$ of $\mathrm{M}$-Kalk and Merit 5000 was $+11.8 \mathrm{eV}$ and $+12.1 \mathrm{eV}$ relative to $\mathrm{E}_{0}$ respectively, which can be compared to the $\mathrm{V}_{2} \mathrm{O}_{3}$ standard for which $\mathrm{E}_{1 / 2}$ was $+11.9 \mathrm{eV}$. In the blast furnace, iron oxides are converted to metallic iron under high temperature $\left(\sim 1500^{\circ} \mathrm{C}\right)$ and reductive conditions. Hence, the occurrence of low vanadium valence states in the blast furnace slag is expected. As the $\mathrm{E}_{1 / 2}$ and the pre-edge peak intensity of the vanadium K-edge XANES spectra are positively correlated [29], they are commonly compared to vanadium standards to establish vanadium valence states [36, 37]. Vanadium(II) lacks a pre-edge peak [29] and the intensities of the pre-edge peaks in the BF slag spectra were half of the intensity measured in the $\mathrm{V}_{2} \mathrm{O}_{3}$ standard. However, they corresponded well to the intensities reported for vanadium(III) compounds in the literature, ranging from 0.06 to 0.08 [26, 29, 38]. The $\mathrm{E}_{1 / 2}$ of the slags was in the same range as the $\mathrm{V}_{2} \mathrm{O}_{3}$ standard. Hence the most probable conclusion is that the $\mathrm{BF}$ slags mainly contain vanadium(III). Possibly there may be a minor contribution from vanadium(II), but this cannot be confirmed from the obtained spectra. 
Vanadium speciation in soils is important from a toxicological point of view since the pentavalent vanadate is vanadium(III), but water leachates of M-Kalk and Merit 5000 consisted mainly of vanadium(IV) (Figure 2, Table 3). In the sorption experiments performed on the two soils, the Säby soil, which had the highest clay content, sorbed a larger fraction of the added vanadium than the sandy Pustnäs soil. The vanadium valence state in the equilibrated solutions was predominantly vanadium(V), more than $95 \%$ for Pustnäs and about $70 \%$ for Säby (Table 3). Vanadium speciation in the solutions was independent of the vanadium valence state (vanadium(IV) or vanadium(V)) of the salt that was added to the soil. Additional vanadium K-edge XANES spectra of the soils showed that the native vanadium in the reference soils mainly consisted of vanadium(IV) (Supplementary content). In soil samples to which vanadate(V) had been added, the oxidation state increased to between +4 and +5 . This indicates that most of the added vanadium remained as vanadate $(\mathrm{V})$ in these soils, which is in agreement with the solution speciation results.

In soils, only vanadium in the oxidation states +4 and +5 are expected to be leached [17]. As shown in the sorption experiments, vanadium(V) dominated in the soil extracts. Further, vanadium speciation was independent of the vanadium species added to the soils, illustrating that oxidation/reduction reactions occur rapidly. This observation is consistent with the study of Wehrli et al. [39] who showed that the redox reactions of vanadium are fast and catalyzed by surface reactions involving e.g. Fe (hydr)oxides in the soil. The predominance of vanadium(IV) in the slag leachates may be due to the reducing conditions under which the slag was formed. Laboratory column tests performed on BF slags have shown that the redox potential is lowered due to the buffering by e.g. sulphide present in the slag [8]. When the slag is mixed into a soil, the redox potential is expected to increase on atmospheric contact. Hence vanadium(V) may be oxidized to vanadium(V) in the dissolved phase. The relative proportions of vanadium(IV) and vanadium(V) at equilibrium are likely related to $\mathrm{pH}$, redox potential and to the interactions with dissolved organic matter (DOM) which reduces vanadium(V) to vanadium(IV) when complexed to DOM [18, Larsson et al. in prep.].

\subsection{Soils amended with blast furnace slag}

The vanadium recovery in the soils amended with BF slag was evaluated by comparing the aqua regia extracted vanadium concentrations to the nominal vanadium concentrations, i.e. the vanadium concentration in the untreated control soils summed with the vanadium added by BF slag. The vanadium recovery ranged between 70 and $111 \%$, indicating little leaching. The variation in vanadium recovery may have been influenced by the 
difficulty to collect a representative sample of the slag-amended soil. One exception was the $29 \%$ addition of Mvanadium loss of about $120 \mathrm{mg} \mathrm{V} \mathrm{kg}^{-1}$ soil. The $0.01 \mathrm{M} \mathrm{CaCl}_{2}$ extracts $\left(1 \mathrm{~L} \mathrm{~kg}^{-1}\right.$ soil) contained 0.12 and 0.028 $\mathrm{mg} \mathrm{V} \mathrm{L}{ }^{-1}$ in the Pustnäs and Säby soil, respectively. Assuming a maximum of $900 \mathrm{~mm}$ of precipitation passing through a $20 \mathrm{~cm}$ soil layer in one year (i.e. $3 \mathrm{~L}_{\text {water }} \mathrm{kg}^{-1}$ soil), this would correspond to an annual vanadium leaching of 0.36 and $0.084 \mathrm{mg} \mathrm{V} \mathrm{kg}^{-1}$ soil, respectively. Hence, it would be unrealistic to suppose that the unrecovered vanadium was due to leaching and the low recovery is therefore likely an analytical error. M-kalk had a larger grain size compared to Merit 5000 (Table 2) which may have caused a more uneven spreading of the vanadium in the soil.

The soil $\mathrm{pH}$ increased gradually with slag dose from about $\mathrm{pH} 5.5$ (control) to $\mathrm{pH} 8$ (29 \% BF slag addition). Additions of $5 \% \mathrm{CaCO}_{3}$ yielded a $\mathrm{pH}$ value close to the $10 \%$ slag application. There was no general trend in dissolved organic carbon concentrations for the different slag additions (details not shown).

\subsection{Plant growth and vanadium uptake}

Additions of up to $29 \%$ of BF slag did not decrease barley plant biomass except in one treatment with the highest slag dose of M-kalk in the Säby soil (Figure 3). Shoots of barley seedlings grown in the control soils contained, on average, $0.20 \mathrm{mg} \mathrm{V} \mathrm{kg}^{-1}$ dry weight (dw). These concentrations increased significantly with increasing BF slag addition (increasing soil vanadium concentration) up to a maximum of 0.34 and $0.42 \mathrm{mg} \mathrm{V}$ $\mathrm{kg}^{-1} \mathrm{dw}$ in the Pustnäs soil treated with $29 \%$ of M-Kalk and Merit 5000 respectively. The vanadium concentrations in plants grown in the Säby soil amended with BF slags were generally lower than in the more sandy Pustnäs soil. It has previsouly been shown that the Säby soil has a higher vanadium sorption strength compared to the Pustnäs soil [15]. This was also observed in the sorption experiments (Table 3), in which the Säby soil sorbed a higher percentage of the added vanadium than the Pustnäs soil.

The results of the plant growth assays confirmed earlier observations that toxicity assays performed on soils freshly spiked with metal salts have a relatively large fraction of bioavailable metal [35]. The EC50 values for barley plants grown in freshly spiked Pustnäs and Säby soils were 87 and $230 \mathrm{mg} \mathrm{V} \mathrm{kg}^{-1}$ soil respectively [15]. The threshold values increased to $>180$ and $530 \mathrm{mg} \mathrm{V} \mathrm{kg}^{-1}$ after 10 months of ageing [25]. In comparison, the BF slag-amended soils reached a maximum soil vanadium concentration of $150 \mathrm{mg} \mathrm{V} \mathrm{kg}{ }^{-1}$ soil. Plant growth was significantly reduced only in one treatment (Säby soil amended with $29 \%$ M-kalk). However, in this treatment, the soil solution and plant vanadium concentrations were lower than those required to cause toxicity in the aged 
soils. Hence, the significantly lower plant biomass was most likely due to other reasons, such as changes in physical properties of the soil or increased $\mathrm{pH}$, which might have induced trace element deficiency.

There was a linear relationship between the vanadium concentrations in the plants and the aqua regia-extractable vanadium concentrations in the soils (Figure 4). The linear regression lines were statistically significant for all treatments in the Pustnäs soil but only for the freshly spiked Säby soil. The slopes of the regressions were steeper in the freshly spiked soil than in the slag amended soils. The bioavailability of the aqua regia-soluble vanadium in the BF slag amended soils, relative to the freshly spiked soils $\left(\mathrm{RBA}_{\mathrm{V}}\right)$ was between 0.08 and 0.32 (Table 4$)$. The lowest RBA $\mathrm{V}_{\mathrm{V}}$ was found in the Pustnäs soil, for which the absolute bioavailability (barley shoot vanadium concentration) was highest. Concerning the aged soils, the RBAV of the aged Pustnäs soil was higher compared to the same soil amended with BF slags. For the Säby soil, the RBA $A_{V}$ values were not significantly different from zero as the increase in plant vanadium was not statistically significant with the exception of the freshly spiked soils. When data from all treatments were combined, the plant vanadium concentration was better related to the dissolved vanadium concentration in the soil than to the aqua regia-soluble soil vanadium (Figure 5). This is consistent with a previous study, in which we proposed that the dissolved vanadium concentration in the soil solution is a better estimate for the toxic vanadium dose in different soils compared to the aqua regia-soluble soil vanadium concentration [15]. This observation is again confirmed for different sources of vanadium, soils and ageing times. This suggests that the uptake of vanadate(V) from the soil solution, within the ranges tested in this study, is not largely affected by the $\mathrm{pH}$ or other anions competing with vanadate(V) uptake (e.g. $\left.\mathrm{H}_{2} \mathrm{PO}_{4}{ }^{-}\right)$. Hence, it would be more accurate to base risk assessments on the vanadium concentration in soil solution.

The low $\mathrm{RBA}_{v}$ values in the BF slag-amended soils indicated that only a small fraction of the added vanadium had been leached from the slags during the ageing period. Ten months of incubation is however a relatively short period of time to estimate long-term reactions between the BF slag and the soil. The availability tests carried out by Fällman and Hartlén [8] showed that $10 \%$ of the vanadium may be leached from BF slags. However, these authors also pointed out that the properties of the weathered slag may change over time, which could affect the leaching properties. Previously established vanadium EC10 values for the freshly spiked Pustnäs and Säby soils ranged from 10 to $250 \mathrm{mg}$ added $\mathrm{V} \mathrm{kg}^{-1}$ soil [15]. M-kalk is a material intended for soil amendments and a $1 \%$ addition is a realistic dose. If, however, repeated large applications occur over a long-term perspective this may lead to vanadium additions that exceed the EC10 threshold values expressed on a mg added vanadium $\mathrm{kg}^{-1} \mathrm{soil}^{\mathrm{i}}$ basis. However, this study showed that the total vanadium concentration is a poor predictor of the bioavailability of vanadium and that soil solution should be the basis to estimate the risk of vanadium in slag amended soils. 


\section{Conclusion}

The toxicity tests that were performed on barley shoots grown in vanadium-rich soils, through BF slag amendments, showed no negative impact on barley shoot growth due to vanadium. The vanadium pore water concentration is a better indicator when evaluating the risk of vanadium toxicity, compared to the current practice of using guidelines based on total soil concentrations. For BF slags, the low vanadium dissolution suggests a limited risk of vanadium toxicity when applied at low doses. Repeated large applications of BF slag may increase the risk but this should be evaluated on the basis of soil solution vanadium concentrations to identify acceptable doses.

\section{Acknowledgements}

This research was funded by the Swedish Steel AB Merox, Loussavaara-Kirunavaara Aktiebolag and Rautaruukki Corporation. Use of the Stanford Synchrotron Radiation Lightsource, SLAC National Accelerator Laboratory, is supported by the U.S. Department of Energy, Office of Science, Office of Basic Energy Sciences under Contract No. DE-AC02-76SF00515. The SSRL Structural Molecular Biology Program is supported by the DOE Office of Biological and Environmental Research, and by the National Institutes of Health, National Institute of General Medical Sciences (including P41GM103393). The contents of this publication are solely the responsibility of the authors and do not necessarily represent the official views of NIGMS or NIH. S. Baken acknowledges the FWO-Research Foundation Flanders for a $\mathrm{PhD}$ fellowship. The authors thank Marilena D'Amato and Andrea Raggi for performing the DRC-ICP-MS and HPLC-ICP-MS measurements. 


\section{References}

[1] Worldsteel, Steel Statistical Yearbook 2013, in, Worldsteel Commitee on Economic Studies - Brussels, 2013. [2] B. Das, S. Prakash, P.S.R. Reddy, V.N. Misra, An overview of utilization of slag and sludge from steel industries, Resources, Conservation and Recycling, 50 (2007) 40-57.

[3] N.M. Piatak, M.B. Parsons, R.R. Seal Ii, Characteristics and environmental aspects of slag: A review, Applied Geochemistry, (in press).

[4] J.O. Nystroem, F. Henriquez, Magmatic features of iron ores of the Kiruna type in Chile and Sweden; ore textures and magnetite geochemistry, Economic Geology, 89 (1994) 820-839.

[5] E. Nehrenheim, J.P. Gustafsson, Kinetic sorption modelling of $\mathrm{Cu}, \mathrm{Ni}, \mathrm{Zn}, \mathrm{Pb}$ and $\mathrm{Cr}$ ions to pine bark and blast furnace slag by using batch experiments, Bioresource Technology, 99 (2008) 1571-1577.

[6] D.M. Proctor, K.A. Fehling, E.C. Shay, J.L. Wittenborn, J.J. Green, C. Avent, R.D. Bigham, M. Connolly, B. Lee, T.O. Shepker, M.A. Zak, Physical and chemical characteristics of blast furnace, basic oxygen furnace, and electric arc furnace steel industry slags, Environmental Science \& Technology, 34 (2000) 1576-1582.

[7] G. Cornelis, C.A. Johnson, T.V. Gerven, C. Vandecasteele, Leaching mechanisms of oxyanionic metalloid and metal species in alkaline solid wastes: A review, Applied Geochemistry, 23 (2008) 955-976.

[8] A.M. Fällman, J. Hartlén, Leaching of slags and ashes - controlling factors in field experiments versus in laboratory tests, in: H.A. van der Sloot, J.J.J.M. Goumans, T.G. Aalbers (Eds.) Studies in Environmental Science, Elsevier, 1994, pp. 39-54.

[9] P. Chaurand, J. Rose, V. Briois, L. Olivi, J.L. Hazemann, O. Proux, J. Domas, J.Y. Bottero, Environmental impacts of steel slag reused in road construction: A crystallographic and molecular (XANES) approach, Journal of Hazardous Materials, 139 (2007) 537-542.

[10] V. Cappuyns, R. Swennen, Release of vanadium from oxidized sediments: insights from different extraction and leaching procedures, Environmental Science and Pollution Research, 21 (2014) 2272-2282.

[11] A. Mikkonen, J. Tummavuori, Retention of vanadium (V) by three Finnish mineral soils, European Journal of Soil Science, 45 (1994) 361-368.

[12] D.I. Kaplan, K.S. Sajwan, D.C. Adriano, S. Gettier, Phytoavailability and toxicity of beryllium and vanadium, Water Air and Soil Pollution, 53 (1990) 203-212.

[13] H.W. Martin, D.I. Kaplan, Temporal changes in cadmium, thallium, and vanadium mobility in soil and phytoavailability under field conditions, Water Air and Soil Pollution, 101 (1998) 399-410. 
[14] H.E. Gäbler, K. Gluh, A. Bahr, J. Utermann, Quantification of vanadium adsorption by German soils, Journal of Geochemical Exploration, 103 (2009) 37-44.

[15] M.A. Larsson, S. Baken, J.P. Gustafsson, G. Hadialhejazi, E. Smolders, Vanadium bioavailability and toxicity to soil microorganisms and plants, Environmental Toxicology and Chemistry, 32 (2013) 2266-2273. [16] A.P. Lehoux, C.L. Lockwood, W.M. Mayes, D.I. Stewart, R.J.G. Mortimer, K. Gruiz, I.T. Burke, Gypsum addition to soils contaminated by red mud: implications for aluminium, arsenic, molybdenum and vanadium solubility, Environmental Geochemistry and Health, 35 (2013) 643-656.

[17] R.B. Wanty, M.B. Goldhaber, Thermodynamics and kinetics of reactions involving vanadium in natural systems: Accumulation of vanadium in sedimentary rocks, Geochimica Et Cosmochimica Acta, 56 (1992) 14711483.

[18] X.Q. Lu, W.D. Johnson, J. Hook, Reaction of vanadate with aquatic humic substances: An ESR and V-51 NMR study, Environmental Science \& Technology, 32 (1998) 2257-2263.

[19] C.L. Peacock, D.M. Sherman, Vanadium(V) adsorption onto goethite (alpha-FeOOH) at pH 1.5 to 12: A surface complexation model based on ab initio molecular geometries and EXAFS spectroscopy, Geochimica Et Cosmochimica Acta, 68 (2004) 1723-1733.

[20] L.E. Seargeant, R.A. Stinson, Inhibition of human alkaline phosphatases by vanadate, Biochem. J., 181 (1979) 247-250.

[21] D.S. Perlin, R.M. Spanswick, Characterization of ATPase activity associated with corn leaf plasmamembranes, Plant Physoilogy, 68 (1981), 521-526.

[22] R. Salminen, M.J. Batista, M. Bidovec, A. Demetriades, B. De Vivo, W. De Vos, M. Duris, A. Gilucis, V. Gregorauskiene, J. Halamic, P. Heitzmann, A. Lima, G. Jordan, G. Klaver, P. Klein, J. Lis, J. Locutura, K. Marsina, A. Mazreku, P.J. O'Connor, S.Å. Olsson, R.-T. Ottesen, V. Petersell, J.A. Plant, S. Reeder, I. Salpeteur, H. Sandström, U. Siewers, A. Steenfelt, T. Tarvainen, Geochemical Atlas of Europe. Part 1: Background Information, Methodology and Maps, in, Espoo, Geological Survey of Finland, 2005.

[23] Naturvårdsverket, Riktvärden för förorenad mark: modellbeskrivning och vägledning, Rapport 5976, 2009, pp. 272.

[24] P.G. Smith, C. Boutin, L. Knopper, Vanadium Pentoxide Phytotoxicity: Effects of Species Selection and Nutrient Concentration, Archives of Environmental Contamination and Toxicology, 64 (2013) 87-96.

[25] S. Baken, M.A. Larsson, J.P. Gustafsson, F. Cubadda, E. Smolders, Ageing of vanadium in soils and consequences for bioavailability, European Journal of Soil Science, 63 (2012) 839-847. 
[26] P. Chaurand, J. Rose, V. Briois, M. Salome, O. Proux, V. Nassif, L. Olivi, J. Susini, J.L. Hazemann, J.Y.

Bottero, New methodological approach for the vanadium K-edge X-ray absorption near-edge structure interpretation: Application to the speciation of vanadium in oxide phases from steel slag, Journal of Physical Chemistry B, 111 (2007) 5101-5110.

[27] A. Thompson, D. Attwood, E. Gullikson, M. Howells, K.-J. Kim, J. Kirz, J. Kortright, I. Lindau, Y. Liu, P. Pianetta, A. Robinson, J. Scofield, J. Underwood, G. Williams, H. Winick, X-ray Data Booklet, Lawrence Berkely National Laboratory, University of California, Berkely, California 94720, 2009.

[28] B. Ravel, M. Newville, ATHENA, ARTEMIS, HEPHAESTUS: data analysis for X-ray absorption spectroscopy using IFEFFIT, Journal of Synchrotron Radiation, 12 (2005) 537-541.

[29] J. Wong, F.W. Lytle, R.P. Messmer, D.H. Maylotte, K-edge absorption spectra of selected vanadium compounds, Physical Review B, 30 (1984) 5596-5610.

[30] T.V. Komarova, O.N. Obrezkov, O.A. Shpigun, Ion chromatographic behaviour of anionic EDTA complexes of vanadium(IV) and vanadium(V), Analytica Chimica Acta, 254 (1991) 61-63.

[31] F. Aureli, S. Ciardullo, M. Pagano, A. Raggi, F. Cubadda, Speciation of vanadium(IV) and (V) in mineral water by anion exchange liquid chromatography-inductively coupled plasma mass spectrometry after EDTA complexation, Journal of Analytical Atomic Spectrometry, 23 (2008) 1009-1016.

[32] International Organization for Standardization (ISO), Soil quality - Determination of the effects of pollutants on soil flora - Part 2: Effects of chemicals on the emergence and growth of higher plants. ISO 112692, in, Geneve, Switzerland, 2005.

[33] J. Lynch, Provisional Elemental Values for Eight New Geochemical Lake Sediment and Stream Sediment Reference Materials LKSD-1, LKSD-2, LKSD-3, LKSD-4, STSD-1, STSD-2, STSD-3 and STSD-4*, Geostandards Newsletter, 14 (1990) 153-167.

[34] WEPAL, Certificate of Analysis-International Soil-Analytical Exchange Reference Material 918, in, Wageningen University, Wageningen, 2007.

[35] E. Smolders, K. Oorts, P. van Sprang, I. Schoeters, C.R. Janssen, S.P. McGrath, M.J. McLaughlin, Toxicity of trace metals in soil as affected by soil type and aging after contamination: using calibrated bioavailability models to set ecological soil standards, Environmental Toxicology and Chemistry, 28 (2009) 1633-1642. [36] S.R. Sutton, J. Karner, J. Papike, J.S. Delaney, C. Shearer, M. Newville, P. Eng, M. Rivers, M.D. Dyar, Vanadium K edge XANES of synthetic and natural basaltic glasses and application to microscale oxygen barometry, Geochimica Et Cosmochimica Acta, 69 (2005) 2333-2348. 
[37] I.T. Burke, W.M. Mayes, C.L. Peacock, A.P. Brown, A.P. Jarvis, K. Gruiz, Speciation of Arsenic,

Chromium, and Vanadium in Red Mud Samples from the Ajka Spill Site, Hungary, Environmental Science \& Technology, 46 (2012) 3085-3092.

[38] G. Giuli, E. Paris, J. Mungall, C. Romano, D., Dingwell, V oxidation state and coordination number in silicate glasses by XAS, American Mineralogist, 89 (2004), 1640-1646.

[39] B. Wehrli, B. Sulzberger, W. Stumm, Redox processes catalyzed by hydrous oxide surfaces, Chemical Geology, 78 (1989), 167-179. 


\section{Figure Captions:}

Figure 1. Normalized vanadium K-edge XANES spectra for two blast furnace slags, M-Kalk and Merit 5000, together with two vanadium laboratory standards, $\mathrm{V}_{2} \mathrm{O}_{3(\mathrm{~s})}$ and $\mathrm{V}_{2} \mathrm{O}_{4(\mathrm{~s})}$.

Figure 2. HPLC-ICP-MS chromatograms of water extracts of the two blast furnace slags, M-Kalk (left) and Merit 5000 (right). The ${ }^{35} \mathrm{Cl}^{16} \mathrm{O}+$ interference is resolved chromatographically and does not affect the detection of the two species of interest, i.e., V(IV) and V(V).

Figure 3. Barley plant biomass (bars, primary $y$-axis) and soil $\mathrm{pH}$ (line, secondary y-axis) in relation to blast furnace slag additions. Two different slags, Merit 5000 and M-Kalk, were added to two different soils, Pustnäs and Säby. Included was also one treatment with $5 \% \mathrm{CaCO}_{3}$ (light grey bars). Bars denoted by an asterisk are significantly different from the zero treatment (Dunnett's test, $\alpha=0.95$ ).

Figure 4. The vanadium concentration in barley shoots plotted against the aqua regia extracted soil vanadium in two soils, Pustnäs (left) and Säby (right). The soils were subjected to four different vanadium treatments; freshly spiked $(\mathbf{x})$, aged $(\Delta)$, Merit $5000(\bullet)$ and M-Kalk $(\circ)$, to which linear regression lines were fitted.

Figure 5. The vanadium barley shoot concentration in relation to the vanadium concentration in aqua regia digested soil (left) and in the dissolved phase of the soil (right). Included are data from two different soils, Pustnäs and Säby, which were treated with vanadate (x), and two different blast furnace slags, M-kalk and Merit $5000(\bullet)$. Linear regression lines, plotted on a log-log scale, were fitted to the whole data set, $\mathrm{R}^{2}=0.72$ (left, $n=71)$ and $\mathrm{R}^{2}=0.95$ (right, $\left.n=64\right)$. 
Table 1. Background information and chemical composition of two blast furnace slags, M-kalk and Merit 5000.

\begin{tabular}{lcc}
\hline & M-kalk & Merit 5000 \\
\hline Cooling process & Air & Water \\
Use & Soil amendments & Cement component \\
Production year & $2006-2008$ & $2006-2009$ \\
Grain size, mm & $0.075-2$ & $<0.063$ \\
$\quad$ Oxides $(\%)$ & & \\
$\mathrm{SiO}_{2}$ & 35 & 35 \\
$\mathrm{CaO}$ & 30 & 30 \\
$\mathrm{Al}_{2} \mathrm{O}_{3}$ & 13 & 14 \\
$\mathrm{MgO}$ & 17 & 17 \\
Elements (mg kg & \\
$\mathrm{Ba}$ & & 456 \\
$\mathrm{Cr}$ & 437 & 95 \\
$\mathrm{~S}$ & 106 & 8010 \\
$\mathrm{~V}$ (real total) & 9440 & 783 \\
$\mathrm{~V}$ (aqua regia soluble) & 803 & 560 \\
\hline
\end{tabular}

Table 2. Selected properties of two Swedish soils, Uppland county. The $\mathrm{pH}$ was measured in $0.01 \mathrm{M}$ $\mathrm{CaCl}_{2}$ and the vanadium concentrations were established by aqua regia extractions. The iron and aluminium content were determined by oxalate extractions $\left(\mathrm{Fe}_{\mathrm{ox}}\right.$ and $\left.\mathrm{Al}_{\mathrm{ox}}\right)$.

\begin{tabular}{lcc}
\hline & Pustnäs & Säby \\
\hline Land Use & Grassland & Arable land \\
Sand $(\%)$ & 86 & 34 \\
Clay $(\%)$ & 11 & 29 \\
$\mathrm{pH}$ & 5.9 & 5.5 \\
Org. C (\%) & 1.1 & 2.5 \\
$\mathrm{~V}\left(\mathrm{mg} \mathrm{kg}^{-1}\right)$ & 28 & 43 \\
$\mathrm{Fe}_{\mathrm{OX}}\left(\mathrm{g} \mathrm{kg}^{-1}\right)$ & 1.43 & 4.42 \\
$\mathrm{Al} \mathrm{OXX}_{\mathrm{O} \mathrm{kg}}\left(\mathrm{g} \mathrm{k}^{-1}\right)$ & 0.76 & 1.26 \\
\hline
\end{tabular}


Table 3. The total vanadium concentration and the fraction of vanadium(IV) and vanadium(V) in solutions equilibrated with two blast furnace slags, M-Kalk and Merit 5000, and two soils, Pustnäs and Säby. The blast furnace slags were equilibrated for $24 \mathrm{hrs}$ with water (slag:solution 1:2). The soils were equilibrated for ten days with a $0.03 \mathrm{M} \mathrm{NaNO}_{3}$ solution (soil:solution 2:30) to which $114.5 \mathrm{mg} \mathrm{V}$ $\mathrm{kg}^{-1}$ soil of vanadium(IV), $\mathrm{VO}^{2+}(\mathrm{aq})$, or vanadium(V), $\mathrm{H}_{2} \mathrm{VO}_{4}^{-}(\mathrm{aq})$, was added.

\begin{tabular}{|c|c|c|c|c|c|}
\hline & pH & Sorbed & Dissolved & & \\
\hline & & & & $\overline{V(I V)}$ & $\mathbf{V}(\mathbf{V})$ \\
\hline & & $\%$ & $\mathrm{mg} \mathrm{L}^{-1}$ & $\%$ & \\
\hline Blast Furnace Slag & & & & & \\
\hline Merit 5000 & 11.5 & na & 0.12 & 96 & 4 \\
\hline M-Kalk & 10.4 & na & 0.05 & 89 & 11 \\
\hline Soil & & & & & \\
\hline Pustnäs $+\mathrm{VO}^{2+}(\mathrm{aq})$ & 6.1 & 74 & 2.00 & 3 & 97 \\
\hline Pustnäs $+\mathrm{H}_{2} \mathrm{VO}_{4}^{-}(\mathrm{aq})$ & 6.0 & 52 & 4.67 & 4 & 96 \\
\hline Säby $+\operatorname{VO}^{2+}(a q)$ & 6.0 & 97 & 0.23 & 32 & 68 \\
\hline Säby $+\mathrm{H}_{2} \mathrm{VO}_{4}^{-}(\mathrm{aq})$ & 6.2 & 94 & 0.42 & 25 & 75 \\
\hline
\end{tabular}

Table 4. The vanadium bioavailability in soils as affected by source and age of vanadium.

\begin{tabular}{lcc}
\hline Soil treatment & $\begin{array}{c}\text { Regression slope }^{\mathrm{a}} \\
\mu \mathrm{g} \mathrm{V} \text { plant/mg V soil }\end{array}$ & $\mathbf{R B A}_{\mathbf{V}}{ }^{\mathrm{b}}$ \\
\cline { 1 - 2 } Pustnäs soil & $22 \pm 0.7^{*}$ & n.a. \\
Freshly spiked & $15 \pm 2.2^{*}$ & $0.68 \pm 0.11$ \\
Aged & $1.7 \pm 0.24^{*}$ & $0.08 \pm 0.01$ \\
M-Kalk & $1.7 \pm 0.34^{*}$ & $0.08 \pm 0.02$ \\
Merit 5000 & \\
Säby soil & $2.5 \pm 0.69^{*}$ & n.a. \\
Freshly spiked & $0.4 \pm 0.38$ & $0.16 \pm 0.16$ \\
Aged & $0.8 \pm 0.47$ & $0.32 \pm 0.21$ \\
M-Kalk & $0.5 \pm 0.27$ & $0.20 \pm 0.12$ \\
Merit 5000 & ${ }^{\mathrm{a}}$ Slopes (with standard error) of regression lines between plant vanadium and soil vanadium concentrations (Figure 2). \\
& b The relative vanadium availability factor (RBAv) is the ratio of slopes to that of the freshly spiked treatments, i.e. the factor bioavailability \\
(with standard error) of aqua regia soluble vanadium in the soil relative to that in corresponding freshly spiked soils. \\
* Statistically significant from 0 ( $p<0.05$ )
\end{tabular}




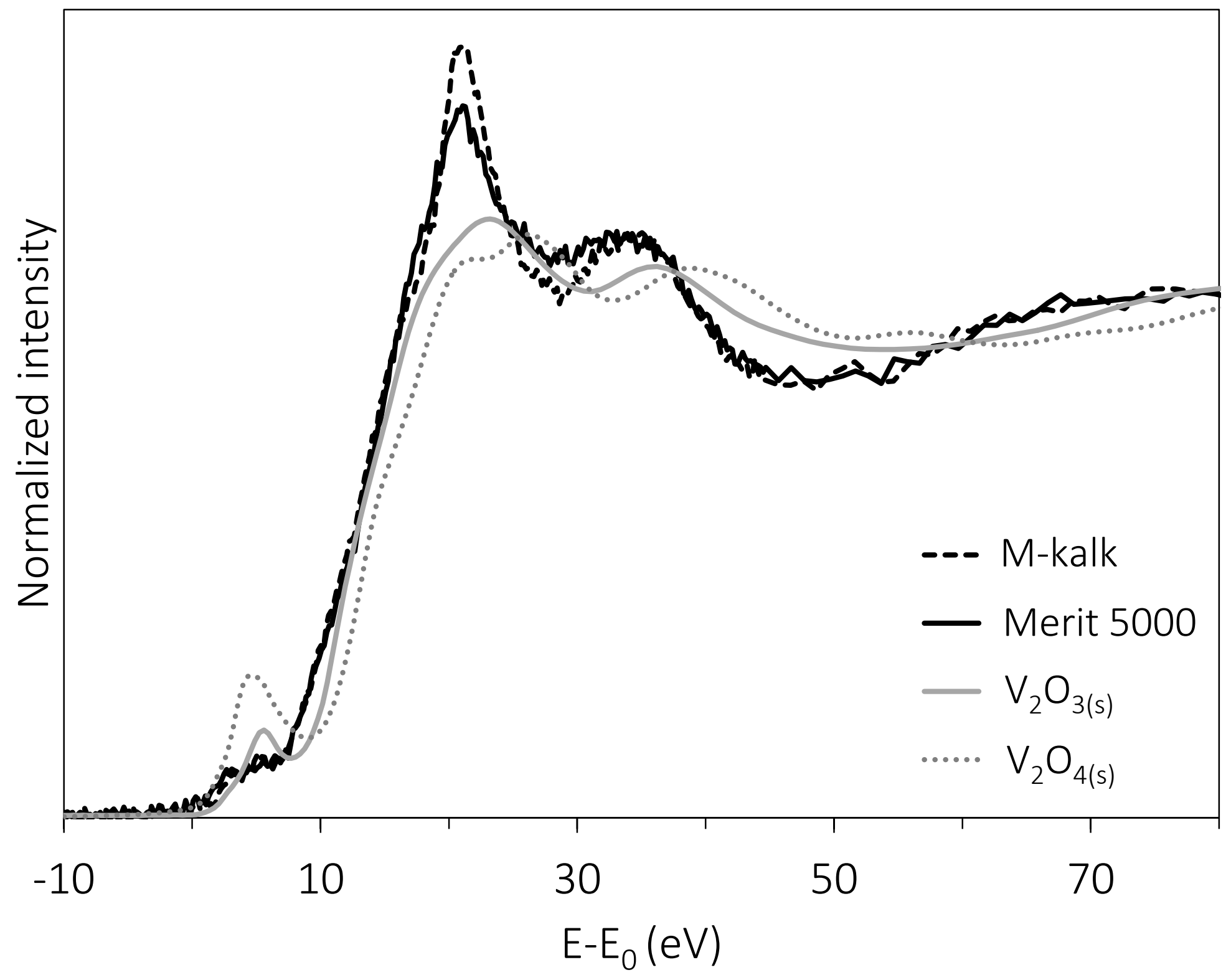



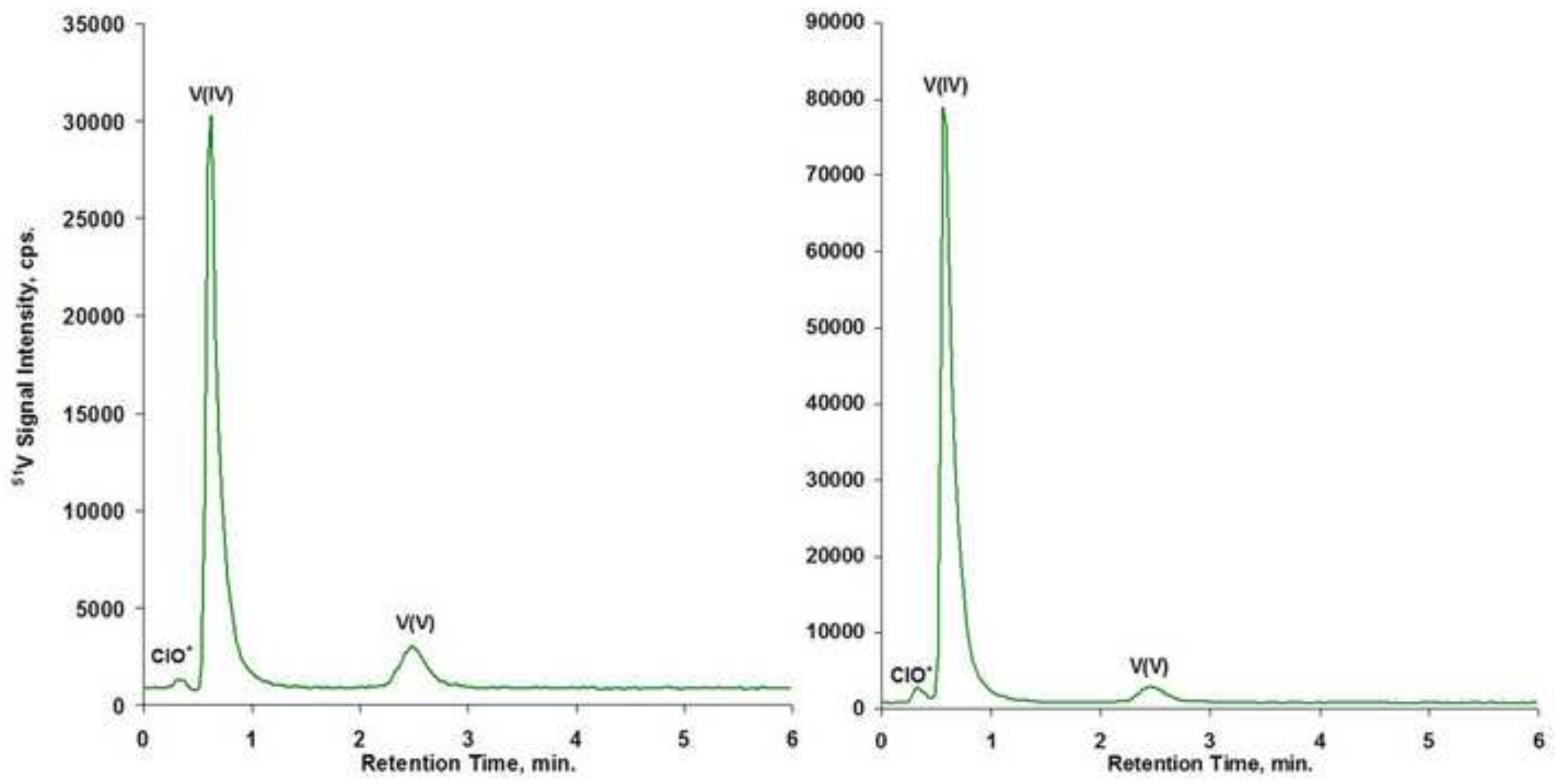
Pustnās, M-Kalk
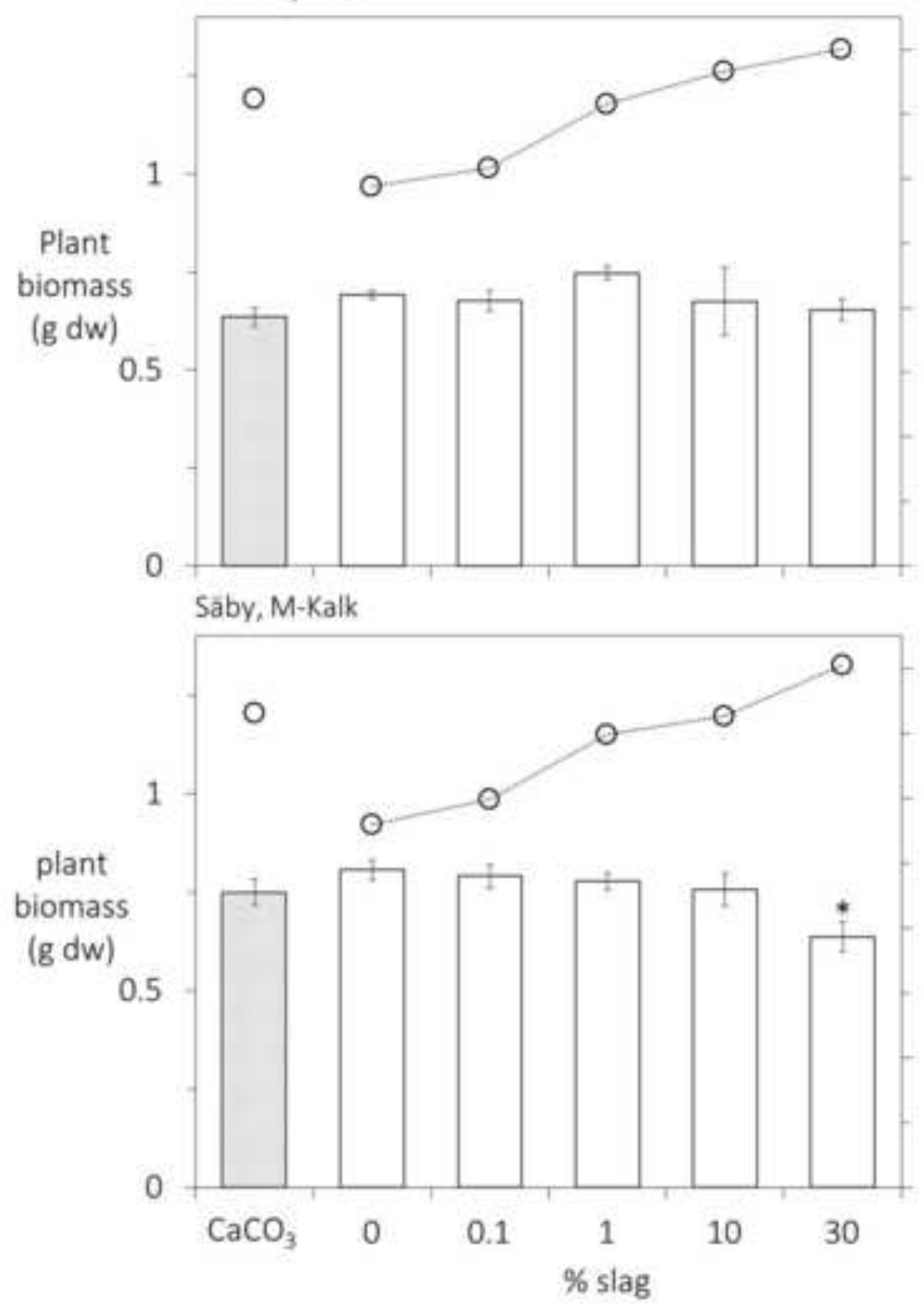

Pustnās, Merit 5000
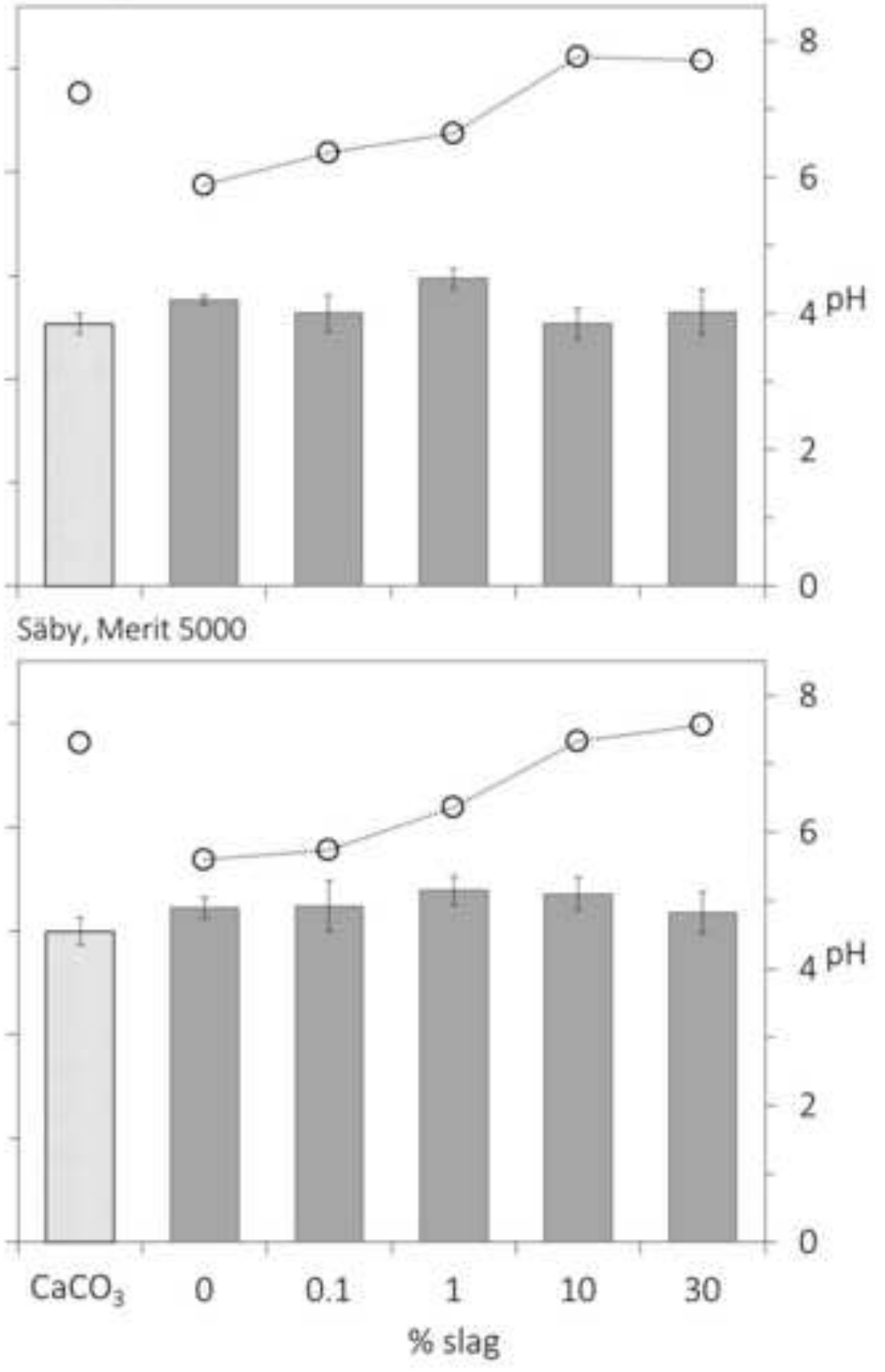

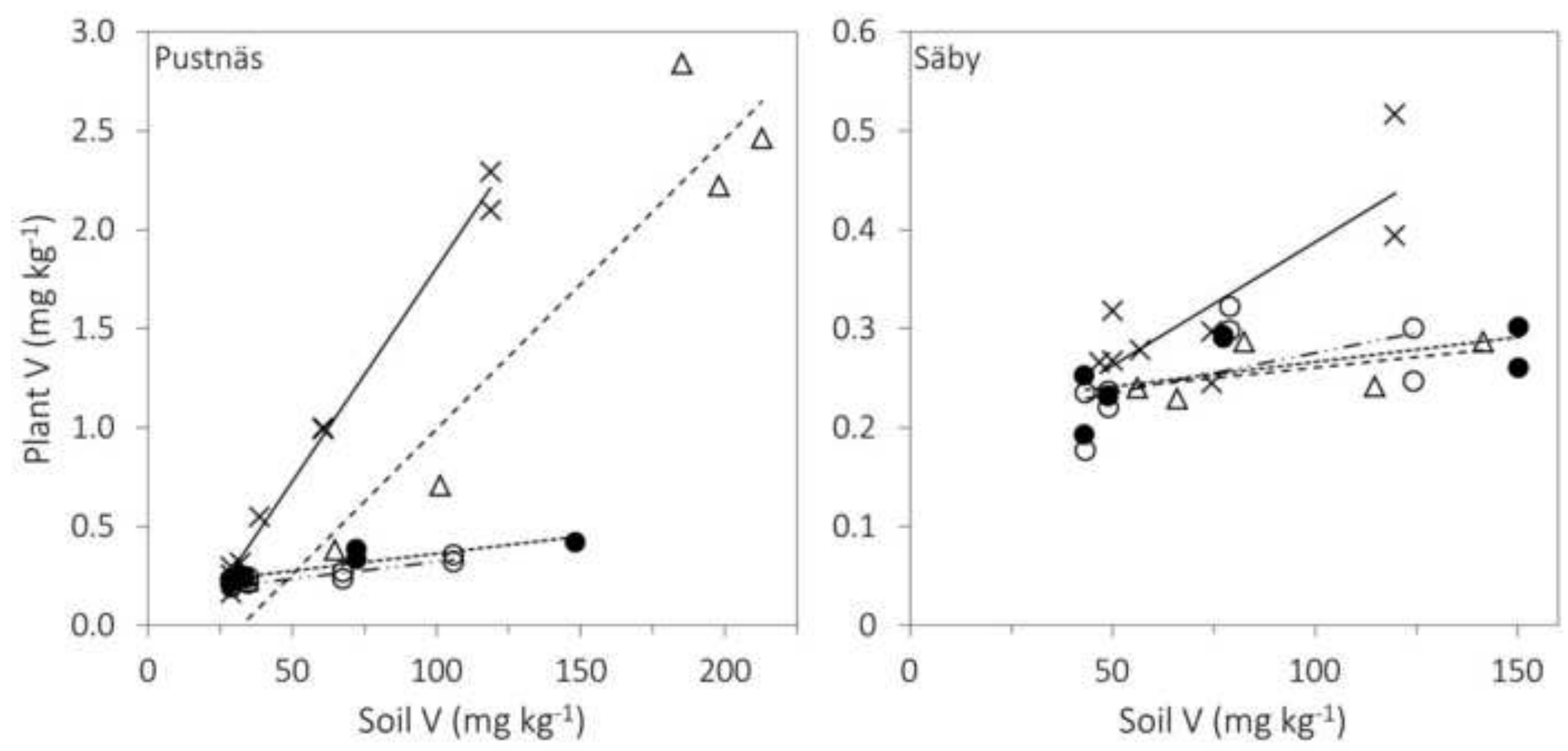
